5 Maher A. Sughayer ${ }^{a^{*}}$, Asem Mansour ${ }^{b}$, Abeer Al Nuirat ${ }^{a}$, Lina Souan ${ }^{a}$, Rashid

6 Abdel-Razeq $q^{\text {a, Mahmoud Siag }}{ }^{\mathrm{a}}$

$8 \quad$ Department of Pathology and Laboratory Medicine, King Hussein

9 Cancer Center, Amman, Jordan

${ }^{b}$ Department of radiology, and CEO, King Hussein Cancer Center 


\section{A second dramatic rise in seroprevalence rates of SARS-CoV-2 antibodies among adult healthy blood donors in Jordan; have we achieved herd immunity?}

Objectives: To determine the impact of the second wave of COVID-19 and the vaccination

campaign on the seroprevalence rates of SARS-CoV-2 antibodies among healthy blood donors

27 in Jordan.

Methods: Sera from 536 healthy adult blood donors collected in June - 2021 were tested using a spike (S) protein receptor binding domain (RBD) of the SARS-CoV-2. confirmed to have been previously infected, $245(61.4 \%)$ have received at least one dose of the vaccine and $123(30.8 \%)$ were neither diagnosed nor vaccinated. The seropositive donors were significantly more likely to have been vaccinated or previously infected. 
medRxiv preprint doi: https://doi.org/10.1101/2021.08.15.21261584; this version posted August 18, 2021. The copyright holder for this preprint (which was not certified by peer review) is the author/funder, who has granted medRxiv a license to display the preprint in perpetuity.

It is made available under a CC-BY-ND 4.0 International license .

41 In a previous issue of International Journal of Infectious Diseases (Sughayer et al, 2021), we

42 reported a dramatic rise in seroprevalence rates of SARS-CoV-2 in healthy blood donors from

$430 \%$ during the months of January to September 2020 up to $27.4 \%$ in late January- early

44 February 2021, just after the end of the first wave of COVID-19 in Jordan. None of the blood

45 donors had received any vaccination by that time.

A second wave of COVID-19 infection started in March and ended in May, 2021. Also a national

vaccination campaign has been ongoing since January of this year. To date approximately 3

million adults have received at least one dose of the COVID-19 vaccine and around 770,000

were PCR-confirmed COVID-19 infected (Ministry of Health-Jordan, 2021). Currently 90\% of the

new cases are caused by the delta variant.

52 To assess the impact of the second wave of COVID-19 and the vaccination on the

53 seroprevalence of SARS-CoV-2 we tested 536 healthy blood donors in June -2021 using a

54 commercially available quantitative assay for the total antibodies including IgG against the

55 spike (S) protein receptor binding domain (RBD) of the SARS-CoV-2: the Elecsys Anti-SARS-CoV-

$56 \quad 2 \mathrm{~S}$ (Roche Diagnostics, Mannheim, Germany). This assay uses a recombinant protein

57 representing the RBD of the $S$ antigen in a double-antigen sandwich assay format, which favors

58 detection of high affinity antibodies against SARS?CoV? 2 . It has a sensitivity of $98.8 \%(95 \% \mathrm{Cl}$ :

$5998.1-99.3 \%)$ and a specificity of $100 \%(95 \% \mathrm{Cl}: 99.7-100 \%)$.

60 The demographics of the blood donors and the results of the serological assay are shown in the 61 table. 


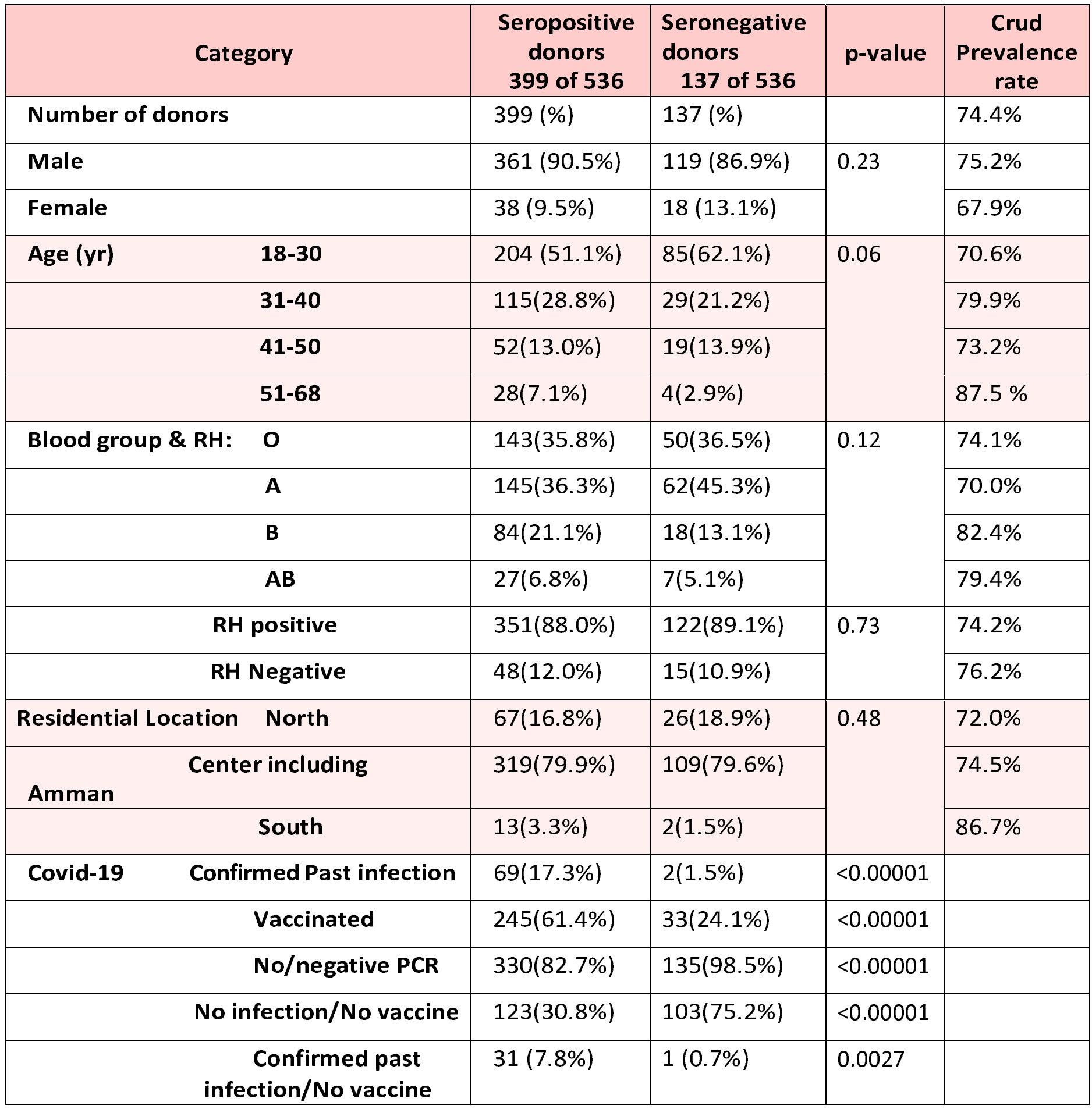


medRxiv preprint doi: https://doi.org/10.1101/2021.08.15.21261584; this version posted August 18, 2021. The copyright holder for this preprint (which was not certified by peer review) is the author/funder, who has granted medRxiv a license to display the preprint in perpetuity.

It is made available under a CC-BY-ND 4.0 International license .

As seen in the table 399 (74.4\%) of the donors were found to be seropositive of whom 245

(61.4\%) have received at least one dose of the vaccine and 69 (17.3\%) were previously infected.

Some of the previously infected have received also at least one dose of the vaccine. A substantial number 123 (30.8\%) of the seropositive donors were neither vaccinated nor had been previously diagnosed with the infection. Interestingly, $33(24.1 \%)$ of the seronegative donors have received the vaccine of whom 29 received only one dose and 4 received 2 doses. While of the vaccinated seropositive donors 119 have received only one dose of the vaccine in contrast to 126 who received full vaccination.

The vaccines types were either Pfizer-BioNTech, Sinopharm, or Astra-Zeneca's. No significant differences were found between the seronegative and seropositive donors in terms of age, sex, blood group or residential location. However the seropositive donors were significantly more

77 likely to have been vaccinated or previously infected. The overall at least one dose-vaccination rate in the entire group of donors is $51.9 \%$. The one-dose vaccination rate in the targeted population of Jordan is currently approximately $45 \%$.

The crude seroprevalence rate of $74.4 \%$ in this group of blood donors may indicate that the

81 Jordanian adult community has attained a substantial rate of herd immunity. The most

82 important question then becomes: what is the level of herd immunity needed in the case of

83 COVID-19 to effectively prevent the transmission?

84 The minimum threshold for herd immunity is theoretically estimated to be $60-72 \%$, however

85 the issue is much more complicated and it may be up to $90 \%$ and even that the entire population needs to be vaccinated/revaccinated to cut the transmission (Kadkhoda, 2021; 
medRxiv preprint doi: https://doi.org/10.1101/2021.08.15.21261584; this version posted August 18, 2021. The copyright holder for this preprint (which was not certified by peer review) is the author/funder, who has granted medRxiv a license to display the preprint in perpetuity.

It is made available under a CC-BY-ND 4.0 International license .

87 Aschwanden, 2020). Therefore we believe that despite of this apparent high level of community

88 immunity we are far from achieving the required herd immunity. Continuation of the

89 vaccination campaign and other precautionary measures of mask-wearing and social distancing

90 are still need to be adhered to.

91

92

93 The Authors declare no conflict of interest.

94 No funding was received.

95 The IRB at King Hussein Cancer Center approved the study

96

97

98 References:

99

100 Aschwanden, C., 2020. The false promise of herd immunity for COVID-19. Nature 587, 26-28.

101 https://doi.org/10.1038/d41586-020-02948-4

102 Kadkhoda, K., 2021. Herd Immunity to COVID-19: Alluring and Elusive. American Journal of

103 Clinical Pathology 155, 471-472. https://doi.org/10.1093/ajcp/aqaa272

104 Ministry of Health, Jordan. https://corona.moh.gov.jo/en (accessed 2.8.2021).

105 Sughayer, M.A., Mansour, A., Al Nuirat, A., Souan, L., Ghanem, M., Siag, M., 2021. Dramatic rise

106 in seroprevalence rates of SARS-CoV-2 antibodies among healthy blood donors: The evolution

107 of a pandemic. International Journal of Infectious Diseases 107, 116-120. 